\title{
The impact of material irregularity provisions of the Public Audit Act on accountability, oversight and governance in the Northern Cape province of South Africa
}

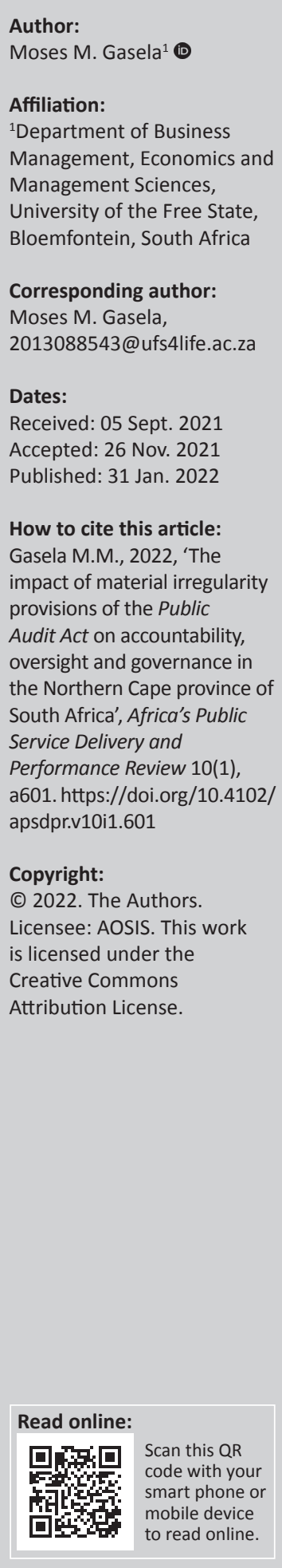

Background: A lot of research on audit-related services and accountability in the international and African contexts has been conducted. However, none of those empirical investigations have been done in the South African context, focussing specifically, on how the material irregularity (MI) of the recently amended Public Audit Act impacts accountability, governance and oversight.

Aim: This study aimed to explore the perceptions of middle and senior managers in the Northern Cape provincial administration on the impact of the implementation of the MI provisions of the amended Public Audit Act on accountability, oversight and governance. The focus of the investigation was the recommendation strand of MI.

Setting: Northern Cape provincial administration with regard to MI provisions of the Public Audit Act in relation to accountability, oversight and governance.

Method: The survey design and a stratified sample of 200 middle and senior managers were used. The response rate was $68.5 \%$. Regression analysis was done.

Results: It was found that the implementation of MI provisions of the amended Public Audit Act positively impacts on accountability, governance and oversight. The MI serves as a deterrent to future wrongdoing in the provincial administration. This finding implies that MI processes have significant value creation and protection in the South African public finances through deterrence even though that cannot be quantified in monetary terms.

Conclusion: The study recommends that government should cooperate and encourage the implementation of the MI provisions to improve accountability, governance and oversight in the event when $\mathrm{MI}$ is detected or suspected during the audit process.

Keywords: material irregularity; accountability; oversight; governance; consequence management; South African public sector.

\section{Introduction and background context of the study}

Worldwide, there is an increasing public pressure for public servants at all levels to be held accountable for their actions; the core of accountability is auditing (Maama \& Marimuthu 2020). The Supreme Audit Institutions (SAIs) play a central role in acting as guarantors of accountability in all spheres of government on the use of public resources (Lima declaration, Gonzalez-Diaz, Garcia-Fernandez \& Lopez-Diaz, 2013; INTOSAI 1977). For the first time in its 110-year old history as a SIA, the Auditor General of South Africa (AGSA) was given an extended mandate, with effect from 01 April 2019, to assist those charged with governance (TCWG) in the South African public sector in the enforcement of consequence management. This would improve accountability in the event that a material irregularity (MI) is detected or suspected during the audit process. The extended mandate stems from the promulgation of Public Audit Amendment Act of 2018 (AGSA consolidated report, 2020).

The main typology of MI is twofold: the recommendation and referral processes. The recommendation process empowers the auditor general to include the recommended actions to resolve a detected $\mathrm{MI}$ in the audit report and take a binding remedial action in the event the accounting officer (AO) or accounting authority (AA) fails to implement the recommended actions, which were previously included in the audit report and issue a certificate of debt (CoD) in the event of a failure to implement a remedial action when a financial loss has occurred or likely 
to occur. The referral process provides the legal authority to the Auditor-General to refer the suspected MI, stemming from the audit process to the relevant public bodies such as the National Prosecuting Authority (NPA), South African Police, Special Investigative Unit (SIU) and so forth for further investigations. The suspected MIs which are referred to the relevant public bodies do not lead to recommendations in the audit report (Public Audit Act, 2018; Public Audit Act Regulations, 2019a).

The literature (such as Matlala \& Uwizeyimana 2020; Transparency International's Corruption Perceptions Index report, 1996 \& 2018; AGSA consolidated reports, 2007 \& 2018) provides a variety of explanations on the antecedents and driving forces behind the promulgation of the Public Audit Amendment Act of 2018. Before its promulgation, evidence and audit insights from the AGSA showed a consistent pattern and a trend of deterioration and regression of various performance matrices within South Africa's public finances value chain, such as the audit outcomes, financial health, service delivery pre-determined objectives, unwanted expenditures (such as irregular expenditure) and noncompliances with key legislation. This happened despite the regular annual warnings by the AGSA when sharing its audit insights, stemming from the annual audits at the three spheres of the South African government (national, provincial and local), including the public entities (AGSA Public Finance Management Act consolidated report, 2007 \& 2018).

According to the AGSA Public Finance Management Act consolidated reports (2007 \& 2018), the irregular expenditure increased over a 10-year period from R1 billion in the financial year (FY) 2006/07 to R45.5 billion in the FY 2017/18 for the provincial and national departments as well as the public entities. This represents a cumulative $4400.09 \%$ increase over the 10-year period whereby the procurement of those goods and services was in contravention with the relevant legislation. This irregular expenditure is potentially understated as some audits were outstanding on the financial reporting date (AGSA PFMA consolidated report, 2018). Furthermore, the audit activities continued to detect prior year irregular expenditures in subsequent audit cycles. Fruitless and wasteful expenditures increased from R77 million in the FY 2006/07 to R2.4 billion in the FY 2017/18, representing a $3087.01 \%$ increase over the 10 -year period. A similar upward trajectory was also observed in unauthorised expenditures whereby they increased over a 10-year period by R1.2 billion, representing a $129.73 \%$ increase. A comparable pattern and trend also emerged over the same 10-year period in the local government sphere of the South African government.

The aforementioned trend and pattern came at an enormous cost to the South African taxpayer, especially as it pertains to the fruitless and wasteful expenditure. Before the promulgation and implementation of the Public Audit Amendment Act of 2018, the mandate of the AGSA was merely 'audit and report', with no mandate to enforce the correction and recovery of pervasive losses, non-compliances with key legislations and so forth, which would be detected during the audit process. According to the AGSA Municipal Finance Management Act (MFMA) Consolidated report (2017) and the AGSA Public Finance Management Act (PFMA) consolidated report (2018), the deterioration of the various performance outcomes in South Africa's public finance value chain is attributable to the inadequate consequence management for poor performance and transgressions, lack of agility in improving controls and addressing risk areas and instability or vacancies in key positions or key officials lacking appropriate competencies. Matlala and Uwizeyimana (2020) echoed the contributions and auditing insights from previous reliable sources (i.e. PFMA AGSA Consolidated report, 2018; MFMA AGSA Consolidated report, 2017) in their contention that empirical studies have showed a trend whereby the auditees in the South African public sector are not taking corrective action on the key audit matters which are raised in prior year audits. This means that some of the key weaknesses and problems are recurring on an annual basis and remain unresolved for a number of years. The works of Matlala and Uwizeyimana (2020) also imply a lack of consequence management and accountability to poor performance that appeared to be wide-spreading before the promulgation of the Public Audit Amendment Act of 2018.

Even though appearing to be in a similar school of thought on the challenges facing the South African public finances compared to all the previous contributions thus far, Transparency International (1996, 2018) approached accountability from a slightly different angle. The evidence from the Corruption Perception Index (CPI) reported by the Transparency International suggests that there was an institutionalisation of endemic corruption in South Africa during the period leading to the promulgation of the Public Audit Amendment Act of 2018. According to the CPI, South Africa was classified as the 23rd least corrupt nation in 1996 out of 180 countries, which was a low historic record. However, in 2018, South Africa was reported as the 73rd least corrupt nations out of the 180 countries, when record all-time high cases of corruption were observed in the country (Corruption Perceptions Index report, 2018 \& 1996).

Furthermore, there is sufficient reliable evidence stemming from the phenomenon, known as 'state capture', in South Africa, which was presented to the Deputy Chief Justice Zondo commission. The estimated cost of state capture is R1.5 trillion, which approximates about a 33\% of the South Africa's gross domestic product (GDP), whilst its qualitative costs include loss of confidence and trust as well as lost opportunity to the government (Johnsen et al. 2019; Corruption Perceptions Index report, 2018 \& 1996; Merten 2019). The World Economic Forum estimated the global cost of corruption to be at least $\$ 2.6$ trillion, or $5 \%$ of the global GDP in 2018.

Given all the aforementioned antecedents and driving forces behind the promulgation of the Public Audit Amendment Act of 2018 , it is obvious that there were public demands from a myriad of stakeholders across the South African spectrum for a 
more aggressive approach to change the aforesaid trajectory in the South African public finances, and improve accountability and consequence management. The AGSA and Standing Committee on Auditor-General (SCOAG) spearheaded the processes leading to the promulgation of the amended Public Audit Act of 2018 (AGSA PFMA consolidated report, 2017). Because of the idiosyncratic nature of MI as well as its endogenous and exogenous risk factors, the AGSA adopted a phased-in implementation strategy of MI. For the PFMA audits, MIs with estimated losses of R6.9 billion were identified in the selected auditees and notified to the AOs/accounting authorities as on 28 February 2021, whilst for the MFMA audits, MIs with the estimated losses valued at around R2.04 billion were identified and reported to the AOs (MFMA AGSA general report, 2020; PFMA general report: 2020).

The lack of consequence management for poor performance and transgressions results in poor accountability and governance in the South African public sector (Matlala \& Uwizeyimana 2020). In South Africa, the inadequate or lack of corrective action on the key audit matters, which were raised in prior year audits, has resulted in the reoccurrences of certain weaknesses and problems on an annual basis and have remained unresolved for a number of years. In Northern Cape Provincial administration in particular, there is a lack of agility in improving controls and addressing risk areas (Matlala \& Uwizeyimana 2020; AGSA MFMA Consolidated report, 2017; AGSA PFMA consolidated report, 2018), which makes it necessary to investigate this state of affairs. It is not quite clear what the impact of the implementation of the MI provisions of the amended Public Audit Act on consequence management, accountability, oversight and governance is, and whether it is a deterrent to future wrongdoing in the Northern Cape Provincial administration. This study, therefore, aimed to examine the impact of the implementation of the MI provisions of the amended Public Audit Act on accountability, oversight and governance, and subsequently recommend mechanisms to enhance accountability, oversight and governance in the Northern Cape provincial administration. In line with the aforementioned study objectives and aim, the focus of the investigation was the recommendation strand of MI, not the referral one.

This article is structured as follows: After the introduction, literature review and theoretical framework are presented in section 'Literature review', research methodology is discussed in section 'Research design and methodology', findings and managerial implications are presented in section 'Results' and finally, conclusion is given.

\section{Literature review \\ Definitions of study key concepts}

In order to locate the study appropriately, the meaning of MI is explored, through a scan of different definitions which will lead to the accepted and adopted definition for purposes of this study. Given that authors attribute the meaning of MI from different perspectives, it is obvious that the construct has different definitions. The Independent
Regulatory Board for Auditors (IRBA) imposes a reporting duty to the South African external auditors to bring the 'reportable irregularities' to its attention. The IRBA (2006) defines a reportable irregularity as:

[A]ny unlawful or omission committed by any person responsible for the management of the entity, which has caused or is likely to cause a material financial loss to the entity or to any partner, member, shareholder, creditor or investor of the entity in respect of his dealings with that entity, or has caused or is likely to cause a material financial loss to the entity or to any partner, member, shareholder, creditor or investor of the entity in respect of his dealings with that entity, or is fraudulent or amounts to theft or represents a material breach of any fiduciary duty owed by such person to the entity or any partner, member, shareholder, creditor or investor of the entity under any law applying to the entity or the conduct or management. (p. 21)

Maroun and Atkins (2014) posited that the construct 'reportable irregularity' as required by IRBA is akin to whistleblowing. From a different school of thought compared to the previous source (IRBA 2006), Public Audit Act regulations (2018) define the MI as:

[A]ny non-compliance with, or contravention of, legislation, fraud, theft or a breach of a fiduciary duty identified during an audit performed under Public Audit Act that resulted in or is likely to result in a material financial loss, the misuse or loss of a material public resource or substantial harm to a public sector institution or the general public. (p. 4)

According to Maluleke (2021), the AGSA is ' ...implementing the new, enhanced powers following the amendment of the Public Audit Act, to further enhance oversight and improve accountability'. In the opinion of Minja (2013), accountability refers to:

$[T]$ he processes by which those who exercise power whether as governments, as elected representatives or as appointed officials, must be able to show that they have exercised their powers and discharged their duties properly. (p. 54)

It is, therefore, evident that MI from the AGSA perspective goes further than a duty to merely report an irregularity which has been uncovered during the audit. The MI empowers the AGSA to take decisive and consequential appropriate actions as deemed appropriate. In their work on investigating the irregularities uncovered during the audit, Hennes, Leone and Miller (2008) argued that irregularities can be classified into two broad categories, namely, intentional acts and unintentional errors. The empirical evidence (e.g. see Tabish \& Jha, 2011; Owusu et al. 2020) reveals that most irregularities in the public sector take place in the procurement of goods and services as well as contract management. This study adopted the definition of MI from the AGSA school of thought as documented above.

\section{Theoretical framework}

The agency theory and contingency theory of accountability were the theoretical point of departure for this study. Moe (1997) and Gwilliam, Macve and Richard (2000) stated that the 
agency theory is the relevant theoretical framework to be used for the analysis of accountability, relationships and effectiveness in government, analysis of incentives for principals and agents to develop more formal as well as rigorous governance arrangements for accountability, and auditing when agents become more remote from principals. According to Colbert and Jahera (1988), the agency theory attempts to provide an explanation for a loss in value which happens whenever one party (agent) acts for another party (principal).

The agency theory has applicability in different settings and contexts (Eisenhardt 1988). In the context of this study, the principals are the South African voters who elect their public representatives in the national parliament and nine provincial legislatures as their agents. The parliament and nine provincial legislatures then become the principals to the executive arm of the government. The executive authorities then function as the principals for the public administration (Johnsen et al., 2018). Based on the aforementioned, it is clear that there is a multi-layer of principals and agents in the context of this study. Karra, Tracey and Phillips (2006) suggested that when there are multi-layers of principals and agents in large and complex organisations, increased agency problems are experienced. These are experienced because of a natural conflict of interest between the agents and the principals in that the agents do not always act in the interest of the principals. Sometimes, the agents make decisions which benefit them and not the principals, resulting in a loss in value. This leads to a dissonance of goal attainment between the principals and agents, which can be aligned through agency control mechanisms (Duh 2010). The agency theory suggests that the SAIs exist as independent, credible and effective public watchdogs to monitor the activities of the agents, provide the feedback on the behaviour of agents to the principals and attest to management's performance for the benefit of the principals and other stakeholders (Colbert \& Jahera 1988; Goolsarran, 2007; Lima INTOSAI 1977).

The contingency theory of accountability suggests that accountability is contextual, depending on a number of factors. The theory proposes two different forms of accountability to be tailored to suit the unique requirements and circumstances of a given context. It postulates that depending on a given context, accountability can be trustbased and/or sanction-based. Asanction-based accountability involves an appropriate sanction being given during the accountability chain. This form of accountability (sanctionbased) is suitable for contexts which are characterised by justified distrust, which stems from unacceptable past actions for the achievement of certain objectives. A trust-based accountability is appropriate in the contexts where justified trust prevails and is highly dependent on giving an account. According to the theory, it is not appropriate to use one-sizefits-all approach in different contexts (Bovens, Goodin \& Schillemans 2014; Harney 2016).

In the context of this study, the contingency theory of accountability has resonance in that the AO and/or AA is first given the opportunity to implement the recommended actions, which are contained in the audit report when the MI has been detected during the audit or is suspected or makes certain representations to the AGSA, supported by reliable sufficient evidence. At the stage of the recommendation process, it is posited that trust-based accountability is being applied. The applicability of a sanction-based accountability which involves a recovery of loss, through a CoD, becomes a last resort when there is justified distrust which is evidenced by the failure to implement the recommended actions reported in the audit report on the MI or suspected one.

\section{Review of the relevant empirical studies}

\section{Deterrence effects}

In the opinion of Renas and Cebula (2005), one of the goals for conducting investigations of possible wrongdoing which may lead to sanctions being subsequently imposed when the malfeasance is found is to deter other organisations and persons from engaging in such behaviour. Continuing from the same line of thought, Zaum (2016) contended that an application of appropriate sanctions in a consistent manner when wrongdoing has been found in the public sector finances deters bad behaviour more effectively. The results from other empirical studies such as studies by Schneider and Wilner (1992) suggest that external audits have the deterrence effects on TCWG on future wrongdoing. This evidence appears to indicate that deterrence effects may include a regulation of behaviour. Earlier studies of Uecker et al. (1981) and Schneider and Wilner $(1990,1992)$ found that internal and external auditing has a strong deterrent effect on the occurrence of irregularities. Since Uecker et al. (1981) and Schneider and Wilner (1990) conducted their reviews, several other empirical studies have been published. These include, from different angles, the works of Long (cited in eds. Kristensen et al. 2019), Di Tella and Schargrodsky (2003), Lagunes (2017), Olken (2007) and Long, Ferraz and Finan (2008), which continued to reveal that increased auditing leads to a reduction in corruption levels through the deterrent effect.

Although the magnitude of the deterrent effect is an empirical issue, it appears that there is a consensus from different studies which were scanned, that audits have a deterrence effect to wrongdoing to a certain extent; encourage TCGW to perform their fiduciary responsibilities, act ethically in the interest of their organisations and have some effect on the regulation of behaviour to avoid negative exposure during the audit process. With the incremental phased-in strategy being pursued by the AGSA on the MI, little is known empirically as to what extent of the deterrence effects does the extended mandate in the South African public sector has, hence, this study was intended to test the following hypothesis:

Hypothesis (1): MI has deterrence effects on future wrongdoing.

\section{Accountability, oversight and governance}

De Martinis and Clark (2003), and Allsworth (2003) are of the view that the auditors of the public sector play a central role in enabling oversight and accountability of governments, especially the executive arm and state-owned entities. 
Similarly, Mazur and Vella (2003) posited that a parliament is able to perform its oversight responsibilities to the executive sphere of government most effectively when it uses and relies on the audit work of the SAI.

The literature appears to suggest that the work of the SAIs improves accountability, oversight and governance. For example, an American and English comparative study by Norton and Smith (2008) revealed that the Government Accountability Office in the United States and the National Audit Office in England ensure accountability of the executive branch of the government. The authors also found that the Government Accountability Office in the United States is more effective compared to its United Kingdom counterpart because of the fact that it derives its legitimacy and powers from the constitution, whilst in England, there is no equivalent document defining the relationship between the state and the citizenry. Rosa and Morote (2016) revealed a positive influence of auditing on accountability. Gustavso and Sundstrom (2018) conducted a comparative international study of more than 100 countries, which used a cross-country analysis to investigate the link between auditing and accountability. Their findings are in line with the earlier studies that auditing contributes to well-functioning and accountable public administrations with a low degree of corruption. In another study that involved the four Nordic countries of Denmark, Finland, Norway and Sweden, Johnsen et al. (2018) explored the influence of auditing by Nordic SAIs on accountability, and revealed that the SAIs' audits have a positive influence on accountability.

The findings of African studies (e.g. Jachie \& Yona, 2019; Maama \& Marimuthu 2020; Masuku 2019; Mzenzi \& Gaspar 2015; Napier 1998; Okpala 2012) confirm the results stemming from the international context, which revealed that auditing has a positive contribution on accountability, oversight and governance in the public sector. Napier (1998) stated that the auditor plays a key role within the governance structures. Okpala (2012) investigated accountability in the Nigerian public sector and found that external auditing plays a significant role in ensuring effective accountability in the public sector of Nigeria. In their works in Tanzanian local government, Mzenzi and Gaspar (2015), however, found that external auditing had marginally contributed to the enhancement of accountability when the scope was widened. From a different angle of internal audit, in Zimbabwe, Jachie and Yona (2019) examined the impact of internal auditing on accountability and also found that auditing is positively associated with accountability. Like Mzenzi and Gaspar (2015), in a Ghanaian study, Maama and Marimuthu (2020) also concluded that external auditing marginally contributes to accountability in the local government. Masuku (2019) considered the South African government as the main actor in the governance of the country. He was of the view that corruption is a consequence of the failure of accountability in the governance system and that effective governance leads to accountability.

The abovementioned empirical findings from different contexts (international and African) consistently highlight that auditing and its related services have a positive contribution to oversight, accountability and governance. However, the extent of the link between the constructs becomes an empirical issue. In the South African context, no empirical investigation has been conducted on the impact of the MIs on accountability, oversight and governance because the extended mandate in terms of the amended Public Audit Act of 2018 came into effect in April 2019. This study, therefore, was intended to fill this gap by testing the following hypothesis:

Hypothesis (2): MI assists in consequence management resulting in positive effect on accountability, governance and oversight.

\section{Potential responses on reported material irregularity}

Because of the multifaceted implications of MI to different affected role players, it is obvious that there will be different reactions and responses when it is identified, and these are: recommended actions on the MIs are reported in the audit reports; implementation follow-ups on recommended actions; pursuance of remedial actions; and so forth. The reactions and responses may vary from acceptance and implementation of the recommended actions and/or remedial actions. There may be differences of opinion, pushbacks and the like. Ordinarily, the international standards of auditing (ISA) such as ISA 701 and INTOSAI Auditing Standards (ISSAI's) such as ISSAI 701 impose specific responsibilities to the auditors to settle the differences of opinion or disagreements with their clients during audits (International Federation of Accountants 2008; INTOSAI 2006).

In their Malaysian study, Rennie, Kopp and Lemon (2014) found that during auditor-client disagreements, the client uses various pressure tactics which may, amongst other things, include threats and litigation to influence the auditors to make concessions. Salleh and Stewart (2012b) found that the Audit Committee can play a crucial mediating role between the auditor and the auditee in the event that there are differences of opinion or disagreements. However, it is evident that the MI is an extended mandate construct, which has additional responsibilities beyond the ISA responsibilities to the auditor.

The AGSA identified the litigation risk/judicial review risk as one of the key risks during the implementation of the MI (AGSA annual report, 2019b). The Intergovernmental Relations Framework Act 2005 established a framework, procedures and mechanisms to settle disputes between state organs. The AGSA is expressly excluded from the Intergovernmental Relations Framework Act 2005. Given that the AGSA and its auditees are state organs, both parties have an opportunity to use the spirit of the Intergovernmental Relations Framework Act 2005 in resolving disputes or differences of opinion stemming from the implementation of MI, even though the AGSA is expressly excluded from the aforesaid Act. Some of the state organs have taken the remedial actions of other chapter institutions such as the public protector on a legal review. There is evidence which confirms that there are instances 
where the auditors receive threats and intimidation from clients during the execution of their professional duties for various reasons such as difference of opinion, uncovering of certain irregularities and so forth. For instance, Warmoll (2015) revealed that Deloitte resigned as auditors of the Rangers International Football Club (RIFC) after being intimidated and threatened repeatedly over a 2-year period of 2013 to 2014. According to Mailovich (2018), there were instances where the AGSA reported acts of intimidation during audits at certain municipalities and had to withdraw their professional staff because of safety concerns.

According to AGSA PFMA consolidated reports (2019), there were a number of pushbacks from certain auditees in the event of regression in audit opinions. Those pushbacks were attributable to the pressure of obtaining clean audits. Furthermore, AGSA MFMA (2017) indicated that the auditing climate for some of the local government clients was increasingly becoming hostile. With the MI being implemented incrementally, the extent of threats and intimidation stemming from either the recommendation or referral processes of $\mathrm{MI}$ is not known, hence the need for this research endeavour.

\section{Research design and methodology}

This study was positioned within the positivist/postpositivist paradigm (Krauss 2005; Thanh \& Thahn 2015). Creswell (2003:7) referred to the post-positivist paradigm as a 'deterministic philosophy in which causes probably determine the effects or outcomes'.

\section{Research design}

Following its positivist philosophical foundations and because of its empirical richness to address the research objectives, this study adopted the survey design and quantitative methods (Leedy \& Ormord 2013; Salant \& Dilman 1994; Pinsonneault \& Karaemen 1993, cited by Glasow 2005). Benbasat, Goldstein and Mead (1987) stated that the survey design has numerous benefits such as enabling the researcher to understand the nature and complexity of the process that is taking place (see also Kraemer 1991 cited by Glasow 2005). Saunders, Lewis and Thornhill (2009) argued that a survey research strategy enables researchers to collect a large amount of data from the sampled population in a fast and economic manner. The deductive reasoning approach was adopted for the study.

\section{Research methodology}

\section{Data collection and analysis}

Population and sample: The target population of the study consisted of senior and middle managers in the Northern Cape Provincial administration. The sampling frame for the study came from the July 2021 consolidated headcount management report, generated from the payroll management system, which listed all the senior and middle managers for the provincial departments making up the Northern Cape provincial administration, namely: Office of the Premier;
Provincial Treasury; Agriculture, Environment Affairs Rural Development Land Reform; Education Department; Health Department; Roads and Public Works; Social Development; Sports, Arts and Culture as well as Transport, Safety and Liaison. The target population was divided into two strata, senior management services (SMS) and middle management services (MMS).

The SMS stratum of the target total population consisted of 220 senior managers in the ranks of directors, chief directors, deputy-directors general, AOs (i.e. Heads of Department) and a director-general. The population size of 220 excluded the Premier and Members of the Executive Council (MECs) in accordance with the study's research aim and objectives. Senior managers were included in the target population because they are responsible for the crafting and implementation of the departmental strategies. During strategy implementation and by virtue of fiduciary responsibilities of their business units and ultimately of the organisation, certain transactions, decisions or nondecisions, performance outcomes and so forth may trigger MI as defined in the Public Audit Act. Maluleke (2021) stated that the AOs are central to the MI implementation.

The MMS stratum of the target population consisted of 800 deputy directors in the entire Northern Cape Provincial administration. The middle managers are the process owners in their business units and are the first line of defence in the departments. By virtue of being process owners in their business units and their role during strategy implementation, certain transactions, process outcomes and decisions may have MI implications during the external audit processes. Medical doctors and school principals were excluded from the target population for they were irrelevant for the study.

The stratified random sampling method was applied (see Diamantopoulos \& Schlegelmilch 2000). For the first stratum of SMS, a random sample of 100 members was selected from the total of 220 SMS members. For the second stratum, a random sample of 100 members was selected from the total of 800 MMS members. This meant that the total sample size for the study was 200 .

Data collection and analysis: A self-administered questionnaire was emailed to the respondents to collect the data. The survey questions were formulated after a detailed literature review was completed, and were guided by the research objectives. The 5-point Likert scale was used. Descriptive and inferential analyses were done, using the multiple regression method.

Reliability and validity, and ethical considerations: Pilot testing of the questionnaire was undertaken. It was sent to five randomly selected SMS and MMS members of the target population. They were excluded from the main study. The feedback from the pilot study was incorporated in the final questionnaire. The study followed all ethical standards for research without direct contact with human subjects. 
TABLE 1: MI, IMPACT, difference, Deterrent and GPP.

\begin{tabular}{|c|c|c|c|c|c|c|c|c|c|c|c|c|c|c|c|}
\hline \multirow[t]{2}{*}{ Variable } & \multicolumn{2}{|c|}{1} & \multicolumn{2}{|c|}{2} & \multicolumn{2}{|c|}{3} & \multicolumn{2}{|c|}{4} & \multicolumn{2}{|c|}{5} & \multirow[t]{2}{*}{ Mean } & \multirow[t]{2}{*}{ SD } & \multirow[t]{2}{*}{$T$} & \multirow[t]{2}{*}{ Prob. } & \multirow[t]{2}{*}{ Decision } \\
\hline & $n$ & $\%$ & $n$ & $\%$ & $n$ & $\%$ & $n$ & $\%$ & $n$ & $\%$ & & & & & \\
\hline \multicolumn{16}{|c|}{ Material irregularity } \\
\hline MI1 & 31 & 22.6 & 84 & 61.3 & 14 & 10.2 & 8 & 5.8 & 0 & 0 & 2 & 0.065 & -15.7 & 0.000 & Reject \\
\hline MI2 & 3 & 2.2 & 41 & 29.9 & 3 & 2.2 & 57 & 41.6 & 33 & 24.1 & 3.6 & 0.104 & 5.4 & 0.000 & Reject \\
\hline MI3 & 18 & 13.1 & 36 & 26.3 & 4 & 2.9 & 54 & 39.4 & 25 & 18.3 & 3.2 & 0.118 & 2.0 & 0.024 & Reject \\
\hline MI4 & 28 & 20.4 & 89 & 65.0 & 16 & 11.7 & 4 & 2.9 & 0 & 0 & 2 & 0.057 & -18.2 & 0.000 & Reject \\
\hline M15 & 26 & 19.1 & 89 & 65.4 & 16 & 11.8 & 5 & 3.7 & 0 & 0 & 2 & 0.059 & -17.2 & 0.000 & Reject \\
\hline MI6 & 57 & 41.9 & 69 & 50.7 & 6 & 4.4 & 4 & 2.9 & 0 & 0 & 1.7 & 0.060 & -22.1 & 0.000 & Reject \\
\hline MI7 & 36 & 26.3 & 78 & 56.9 & 18 & 13.1 & 5 & 3.7 & 0 & 0 & 1.9 & 0.063 & -16.8 & 0.000 & Reject \\
\hline M18 & 31 & 22.6 & 83 & 60.6 & 18 & 13.1 & 5 & 3.7 & 0 & 0 & 2 & 0.061 & -16.8 & 0.000 & Reject \\
\hline MI9 & 26 & 19.0 & 80 & 58.4 & 30 & 21.9 & 1 & 0.7 & 0 & 0 & 2 & 0.057 & -16.9 & 0.000 & Reject \\
\hline MI & - & - & - & - & - & - & - & - & - & - & 2.3 & 0.435 & -19.5 & 0.000 & Reject \\
\hline \multicolumn{16}{|l|}{ Impact } \\
\hline Impact1 & 66 & 48.2 & 61 & 44.5 & 9 & 6.6. & 1 & 0.7 & 0 & 0 & 1.6 & 0.056 & -25.4 & 0.000 & Reject \\
\hline Impact & - & - & - & - & - & - & - & - & - & - & 1.7 & 0.567 & -27.7 & 0.000 & Reject \\
\hline \multicolumn{16}{|l|}{ Difference } \\
\hline Diff1 & 34 & 24.8 & 62 & 45.3 & 28 & 20.4 & 13 & 9.5 & 0 & 0 & 2.1 & 0.077 & -11.1 & 0.000 & Reject \\
\hline Diff2 & 20 & 14.6 & 86 & 62.8 & 20 & 14.6 & 11 & 8.0 & 0 & 0 & 2.2 & 0.066 & -12.8 & 0.000 & Reject \\
\hline Diff3 & 49 & 35.8 & 67 & 48.9 & 13 & 9.5 & 6 & 4.4 & 2 & 1.5 & 1.9 & 0.074 & -15.3 & 0.000 & Reject \\
\hline Diff & - & - & - & - & - & - & - & - & - & - & 2.1 & 0.621 & -17.8 & 0.000 & Reject \\
\hline \multicolumn{16}{|l|}{ Deterrent } \\
\hline Deterr1 & 62 & 45.3 & 60 & 43.8 & 11 & 8.0 & 4 & 2.9 & 0 & 0 & 1.7 & 0.064 & -20.6 & 0.000 & Reject \\
\hline Deterr2 & 64 & 46.7 & 60 & 4.3 .8 & 11 & 8.0 & 2 & 1.5 & 0 & 0 & 1.6 & 0.059 & -22.9 & 0.000 & Reject \\
\hline Deterr3 & 66 & 48.2 & 59 & 43.1 & 12 & 8.8 & 0 & 0 & 0 & 0 & 1.6 & 0.055 & -25.3 & 0.000 & Reject \\
\hline Deterr4 & 73 & 53.3 & 56 & 40.9 & 8 & 5.8 & 0 & 0 & 0 & 0 & 1.5 & 0.052 & -28.4 & 0.000 & Reject \\
\hline Deterr & - & - & - & - & - & - & - & - & - & - & 1.6 & 0.527 & -30.8 & 0.000 & Reject \\
\hline Guidelines & 14 & 10.5 & 19 & 14.2 & 85 & 63.4 & 15 & 11.2 & 1 & 0.8 & 2.8 & 0.810 & -3.2 & 0.001 & Reject \\
\hline
\end{tabular}

Note: Bold values indicate the figures for the variable obtained by combining all the different items used to measure the construct.

\section{Ethical considerations}

Permission to carry out the study was obtained from the Director-General of the Northern Cape provincial administration. In addition, the respondents signed a written informed consent form, indicating their voluntary participation. The respondents were free to discontinue from their participation in the study at any time without any negative consequence.

\section{Results}

\section{Descriptive analysis}

The total response rate is $68.5 \%$. For the SMS subset, the response rate was $67 \%$, whilst for the MMS stratum it was $70 \%$.

\section{Demographic information}

Most respondents were between 45 and 55 years of age; very few were between 56 and 65 years of age. The majority of them $(80.7 \%)$ had a work experience of 11 to 30 years. Almost all the respondents were educated with $51.5 \%$ having an undergraduate degree or diploma and $45.5 \%$ having a post graduate degree or diploma.

\section{Key concepts and constructs}

Table 1 shows the percentage distributions, mean scores as well as the t-test results of the key concepts and constructs of the study. These are: MI (familiarity and understanding of the MI), IMPACT (impact of the MI to accountability, governance and oversight), DIFFERENCE (difference of opinion implications), DETERRENT (deterrent implications of MI) and GPP (guidelines, policies and procedures. The t-test was used to test the null hypothesis that the respondents were uncertain about a statement (i.e. mean score $=3$ ), using the significance level of Alpha $=0.05$. If the $t$-value was negative and its corresponding $p$-value was less than 0.05 , this would mean that the respondents agreed with the statement. However, if the $t$-value was positive and its corresponding $p$-value was less than 0.05 , this would mean that they disagreed with the statement, otherwise, they were uncertain.

The construct of MI was measured by using nine statements. According to Table 1, there is a clear indication that the respondents, in general, agreed with most of the statements (i.e. 7 out of 9). They were not very sure about two statements, namely, MI2 (I have heard about the new powers (MI) of the AGSA but I know very little or nothing about it) and MI3 (My understanding about the new powers (MI) of the AGSA is very little or nothing but I am more open to learn about it and how it affects my area of responsibility in the organisation). Similar to MI, the respondents seemingly agreed with all the statements that measured this construct. For DIFFERENCE, the respondents agreed with all the statements that measured the construct in general. It is not clear whether the respondents agreed or disagreed with the statements that were used to measure the construct, DETERRENT, because the percentages 
TABLE 2a: Regression model for deterrent implications of material irregularity.

\begin{tabular}{lccc}
\hline Source & SS & DF & MS \\
\hline Model & 12.415 & 3 & 4.138 \\
Residual & 24.768 & 128 & 0.193 \\
\hline Total & $\mathbf{3 7 . 1 8 3}$ & $\mathbf{1 3 1}$ & $\mathbf{0 . 2 8 4}$ \\
\hline
\end{tabular}

Obs. = 132; $F(3,127)=21.39 ;$ Prob. $=0.000 ;$ Adj $. R^{2}=0.318$.

$\mathrm{SS}$, sum of squares; DF, degrees of freedom; MS, mean squares.

TABLE 2b: Regression model for deterrent implications of material irregularity.

\begin{tabular}{lccccc}
\hline Source & Coef. & Std. dev. & $\boldsymbol{T}$ & Prob. & 95\% Conf. Interval \\
\hline MI & 0.570 & 0.091 & 6.27 & 0.000 & $0.390,0.750$ \\
Difference & 0.297 & 0.065 & 4.60 & 0.000 & $0.169,0.425$ \\
Guidelines & -0.030 & 0.051 & -0.59 & 0.554 & $-0.131,0.071$ \\
Constant & -0.204 & 0.279 & -0.73 & 0.466 & $-0.755,0.348$ \\
\hline
\end{tabular}

$\mathrm{MI}$, material irregularity

TABLE 3a: Regression model for IMPACT.

\begin{tabular}{lccc}
\hline Source & SS & DF & MS \\
\hline Model & 14.981 & 3 & 4.994 \\
Residual & 27.186 & 127 & 0.214 \\
\hline Total & $\mathbf{4 2 . 1 6 8}$ & $\mathbf{1 3 0}$ & $\mathbf{0 . 3 2 4}$ \\
\hline
\end{tabular}

Obs. $=131 ; F(3,127) ; 23.3 ;$ Prob. $=0.000 ;$ Adj. $R^{2}=0.340$.

$\mathrm{SS}$, sum of squares; DF, degrees of freedom; MS, mean squares.

TABLE 3b: Regression model for IMPACT.

\begin{tabular}{lccccc}
\hline Source & Coef. & Std. dev. & $\boldsymbol{T}$ & Prob. & 95\% Conf. Interval \\
\hline MI & 0.670 & 0.096 & 6.99 & 0.000 & $0.480,0.859$ \\
Difference & 0.287 & 0.069 & 4.18 & 0.000 & $0.151,0.423$ \\
Guidelines & -0.016 & 0.054 & -0.29 & 0.770 & $-0.122,0.090$ \\
Constant & -0.425 & 0.294 & -1.45 & 0.150 & $-1.007,0.156$ \\
\hline
\end{tabular}

$\mathrm{MI}$, material irregularity

of both agree and disagree are more or less the same. The null hypothesis that the mean score is equal to 3 was rejected for all the variables. For MI, the respondents agreed with all the statements except statements MI2 and MI3, as indicated above. They agreed with all the statements of the other constructs, that is, IMPACT, DIFFERENCE, DETERRENT and GPP.

\section{Inferential analysis}

In regression analysis, there were two dependent variables, namely, IMPACT and DETERRENT. The independent variables were MI, DIFFERENCE and GPP. The results are discussed as follows.

\section{Deterrent implications of material irregularity}

Table 2 presents the regression model for DETERRENT. The fitted model is highly significant at the 0.01 level of significance, with the adjusted $\mathrm{R}^{2}$ of 0.318 , which means that the model explains $32 \%$ of the variation of the dependent variable. MI and DIFFERENCE are significant at the 0.01 level of significance. Their coefficients are positive, which implies that MI and DIFFERENCE have a positive effect on DETERRENT. The results confirm the hypothesis (1) that MI has deterrence effects on future wrongdoing.

\section{Impact of the material irregularity on accountability, governance and oversight}

Table 3 presents the regression model for IMPACT. The fitted model is highly significant at the 0.01 level of significance, with the adjusted $\mathrm{R}^{2}$ of 0.340 , which means that the model explains $34 \%$ of the variation in the dependent variable. Like in the case of DETERRENT, only two independent variables, that is, MI and DIFFERENCE are significant at the 0.01 level of significance. The coefficients are positive, which implies that MI and DIFFERENCE have a positive effect on IMPACT.

The results confirm hypothesis (2) that MI assists in consequence management resulting in positive effect on accountability, governance and oversight. Hence, MI is a deterrent to future wrongdoing in the Northern Cape Provincial administration and it assists in consequence management, resulting in positive effect on accountability, governance and oversight.

\section{Conclusion}

This study found that the senior and middle managers in the Northern Cape Provincial administration have a good understanding that the recommendation strand of MI can attract recommendations in the audit report, leading to remedial actions and the rest of the steps in the MI chain for wrongdoing. It was also found that MI of the recently amended Public Audit Act positively impacts accountability, governance and oversight. The senior and middle managers know very well that the new powers (MI) serve as a deterrent to future wrongdoing in the Northern Cape Provincial administration because breaking the law or not complying with the applicable legislative and regulatory requirements would affect the organisation. In the event that there is a difference of opinion between the organisation and its auditor on the MI or suspected one, it may be preferable for both parties to establish alternative mechanisms for resolving disputes, rather than the judicial review process, in the spirit of the Intergovernmental Relations Framework Act as both parties are state organs. Currently, the AGSA is expressly excluded from the Intergovernmental Relations Framezwork Act 2005. The new powers (MI) of the AGSA may increase the threats to the safety of the auditors as the implicated official/s may resort to acts of intimidation and violence against the auditors.

The senior and middle managers in the Northern Cape Provincial administration are aware that the MI recommendation in the audit report may lead to remedial actions and the rest of the steps in the MI chain for wrongdoing. It was found that in the Northern Cape Provincial administration, managers know that breaking the law or not complying with the applicable legislative and regulatory requirements would affect the organisation, and that MI may influence the security and safety of auditors by increasing threats to them as the implicated official/s may resort to acts of intimidation and violence against them, thereby supporting Warmoll's (2015) contributions. The preferred dispute resolution mechanism by the management of the Northern Cape Provincial administration in the event of the difference of opinion stemming from the MI finding is to establish and use alternative mechanisms for resolving disputes, 
rather than the judicial review process, in the spirit of the Intergovernmental Relations Framework Act as both parties are state organs. Currently, the AGSA is not a signatory of the Intergovernmental Relations Framework Act 2005.

It was also found that the implementation of MI provisions of the amended Public Audit Act impacts accountability, governance and oversight positively, and that it serves as a deterrent to future wrongdoing in the Northern Cape Provincial administration. The results of this study support the previous empirical findings (e.g. Renas \& Cebula 2005; Zaum 2016) that auditing (Mzenzi \& Gaspar 2015; Gustavso \& Sundstrom 2018; Okpala 2012; Long cited in Johnsen et al., 2018; Jachie \& Yona 2019; eds. Kristensen et al. 2019; Maama \& Marimuthu 2020; Masuku 2019) and an application of appropriate sanctions (Renas \& Cebula 2005; Zaum 2016) in a consistent manner when wrongdoing has been found in the public sector finances tend to deter bad behaviour in the future.

The study recommends that government should cooperate and encourage internal and external auditing, and most importantly, the implementation of MI provisions of the Public Audit Act to accountability, governance and oversight in the Northern Cape province.

\section{Benefits and limitations of the study}

This study will benefit policymakers as well as researchers in the area of public administration. However, the study was limited by the fact that the results cannot be generalised to the whole of South Africa because the sample that was used was not a good representative of all the managers in the entire South African administration sector. For future research, the study can be conducted nationally or in other provinces of South Africa and can be replicated in other contexts. Furthermore, future research should explore in detail the referral strand of MI as it was not in line with the aim and objectives of this study.

\section{Acknowledgements}

The author acknowledges his friend, a very smart and strong-willed woman, who performed a preliminary review on the manuscript and key study constructs just before it was submitted to the journal for consideration. She provided value-adding feedback, insights and perspectives on the phenomenon of interest. She requested to be annonymised for professional reasons.

\section{Competing interests}

The author declares that he has no financial or personal relationships that may have inappropriately influenced him in writing this article.

\section{Author's contributions}

M.M.G. is the sole author of this research article.

\section{Funding information}

This research received no specific grant from any funding agency in the public, commercial or not-for-profit sectors.

\section{Data availability}

Data sharing is not applicable to this article as no new data were created or analysed in this study.

\section{Disclaimer}

The views and opinions expressed in this article are those of the author and do not necessarily reflect the official policy or position of any affiliated agency of the author.

\section{References}

Allsworth, P.R.S., 2003, 'Government auditing in the South Pacific region: A cook Islands perspective', International Journal of Government Auditing 30(2), 1-28.

Auditor-General SA, 2021, '[ANNOUNCEMENT] The auditor-general (AG), Ms Tsakan Maluleke, is pleased to announce the appointment of Mr Vonani Chauke as the new deputy auditor-general with effect from 1 July 2021. \#insideAGSA \#ExecutiveAppointment \#LeadershipMatters', Twitter, viewed 05 July 2021, from https://twitter.com/AuditorGen_SA/status/1402925090166263809

Benbasat, I., Goldstein, D.K. \& Mead, M., 1987, 'The case research strategy in studies of information systems', MIS Quarterly 11(3), 369-386. https://doi. org $/ 10.2307 / 248684$

Bovens, M., Goodin, R.E. \& Schillemans, T., 2014, 'The Oxford handbook of public accountability', Political Science, Comparative Politics, Public Administration. https://doi.org/10.1093/oxfordhb/9780199641253.013.0019

Colbert, J.L. \& Jahera, J.S., 1988, 'The role of the audit and agency theory', Journal of Applied Business Research 4(2), 7-12. https://doi.org/10.19030/jabr.v4i2.6427

Creswell, J.W., 2003, Research design: Qualitative, quantitative, and mixed methods approach, Sage, Thousand Oaks, CA.

De Martinis, M. \& Clark, C., 2003, 'The accountability and independence of the AuditorsGeneral of Australia: A comparison of their enabling legislation', Australian Accounting Review 13(3), 26-35. https://doi.org/10.1111/j.1835-2561.2001. tb00169.x

Diamantopoulos, A. \& Schlegelmilch, B.D., 2000, Taking the fear out of data analysis, Cengage Learning EMEA, Ham.

Di Tella, R. \& Schargrodsky, E., 2003, 'The role of wages and auditing during a crackdown on Corruption in the City of Buenos Aires', Journal of Law and Economics 46(1), 269-292. https://doi.org/10.1086/345578

Duh, M., 2010, 'Applying agency theory and the resource-based view in explaining performance differences between family and non-family businesses', Nase Gospodarstvo: NG 56(1/2), 45

Eisenhardt, K.M., 1988, 'Agency and institutional theory explanations: The case of retail sales compensation', Academy of Management Journal 31(3), 488-511. retail sales compensation', Acaden
https://doi.org/10.5465/256457

Ferraz, C. \& Finan, F., 2008, 'Exploring corruption in public financial management: The effects of Brazil's publicly released audit outcomes', Quarterly Journal of Economics 123(2), 703-745. https://doi.org/10.1162/qjec.2008.123.2.703

Glasow, P.A., 2005, Fundamentals of survey research methodology, Mitre Publishers, Mclean.

Gonzalez-Diaz, B., Garcia-Fernandez, R. \& Lopez-Diaz, R., 2013, 'Communication as a transparency and accountability strategy in supreme audit institutions', Administration \& Society 45(5), 583-609. https://doi.org/10.1177/0095399712438376

Goolsarran, S.A., 2007, 'The evolving role of supreme audit institutions', The Journal of Government Financial Management 56(3), 28-32.

Gwilliam, D., Macve, R. \& Richard, G., 2000, 'Principals and agents in crisis: Reforms of accounting and auditing at Lloyd's 1982 - 1986', Accounting History 5(61), 61-92. https://doi,org/10.1177/103237320000500204

Gustavso, M. \& Sundstrom, A., 2018, 'Organizing the Audit Society: Does good auditing generate less public sector corruption?', Administration \& Society 50(10), 1508-1532. https://doi.org/10.1177/0095399716674306

Harney, B., 2016, 'Contigency theory', in S. Johnstone \& A. Wilkinson (eds.), An encyclopedia of human resource management, pp. 72-73, Edward Elgar, Cheltenham.

Hennes, K.M., Leone, A.J. \& Miller, B.P., 2008, 'The importance of distinguishing errors from irregularities in restatement research', The Accounting Review 83(6), 1487-1519. https://doi.org/10.2308/accr.2008.83.6.1487

International Federation of Accountants (IFAC), 2008, Handbook of international auditing, assurance and ethics pronouncements, viewed 28 July 2021, from http://www.ifac.org.

International Organisation of Supreme Audit Institutions (INTOSAI), 1977, La Declaration de Lima, International Standards of Supreme Audit Institutions (ISSAI) No.1, INTOSAI, Viena. 
International Organisation of Supreme Audit Institutions (INTOSAI), 2006, Auditing standards, viewed 28 July 2021, from www.issai.org.

Independent Regulatory Board for Auditors (IRBA), 2006, Reportable irregularities: A guide for registered auditors, IRBA Head Office, Modderfontein.

Jachie, M. \& Yona, L., 2019, 'The impact of ethics \& objectivity of internal auditing personnel on transparency and accountability case of Zimbabwe local authorities' European Journal of Business and Management 11(7), 108-124. https://doi. org/10.7176/EJBM/11-7-09

Johnsen, A., Reichborn-Kjennerud, K., Carrington, T., Jeppesen, K.K., Taro, K. \& Jarmo Vakkuri, J., 2019, 'Supreme audit institutions in a high-impact context: A comparative analysis of performance audit in four Nordic countries', Financial Accountability \& Management.35(2), 158-181. https://doi.org/10.1111/faam.12188

Karra, N., Tracey, P. \& Phillips, N., 2006, 'Altruism and agency in the family firm: Exploring the role of family, Kinship, and Ethnicity', Entrepreneurship Theory and Practice 30(6), 861-877. https://doi.org/10.1111/j.1540-6520.2006.00157.x

Krauss, S.E., 2005, 'Research paradigms and meaning making: Primer', The Qualitative Report 10(4), 758-770.

Kristensen, J.K., Bowen, M., Long, C., Mustapha, S. \& Zrinski, U. (eds.), 2019, PEFA public financial management, and good governance, International Development in Focus, World Bank, Washington, DC. https://doi.org/10.1596/978-1-4648in Focus,

Lagunes, P.F., 2017, Guardians of accountability: A field experiment on corruption and inefficiency in Peru's local public works, International Growth Centre, London.

Leedy, P.D. \& Ormrod, J.E., 2013, The nature and tools of research, in practical research: Planning and design, Pearson Education, Boston, MA

Maama, H. \& Marimuthu, F., 2020, 'Accountability in the Ghanaian local governance structure: Probing the role of external auditing', Problems and Perspectives in Management 18(4), 475-485. https://doi.org/10.21511/ppm.18(4).2020.38

Mailovich, C., 2018, 'Threats to auditor-general's staff "put public interest at risk", warns Kimi Makwetu', Sunday Times, viewed 26 June 2021, from https://www. timeslive.co.za/news/south-africa/2018.

Maroun, W. \& Atkins, J., 2014, 'Whistle-blowing by external auditors in South Africa: Enclosure, efficient bodies and disciplinary power', Accounting, Auditing \& Accountability Journal 27(5), 834-862. httpps://doi.org/10.1108/AAAJ-11-2012 1154

Matlala, L.S. \& Uwizeyimana, D.E., 2020, 'Factors influencing the implementation of the auditor general's recommendations in South African municipalities', African Evaluation Journal 8(1), a464. https://doi.org/10.4102/aej.v8i1.464

Masuku, M.M., 2019, 'Effective governance in South Africa: Reality or myth?', African Journal of Democracy and Governance 6(2 \& 3), 117-134.

Mazur, J., \& Vella, B., 2003, 'Relations between SAls and parliamentary committees', International Journal of Government Auditing 30(1), 16-20.

Merten, M., 2019, 'State capture wipes out third of SA's R4.9-trillion GDP - Neve mind lost trust, confidence, opportunity', Daily Maverick, viewed 30 June 2021 from https://www.dailymaverick.co.za/article/2019-03-01 -state-capture-wipesout-third-of-sas-r4-9-trillion-gdp-never-mind-lost-trust-confidenceopportunity/.

Minja, D., 2013, 'Accountability practice in Kenya's Public Service: Lessons to guide service improvement', International Journal of Business and Management Review 1(4), 54-63.

Moe, T.M., 1997, 'The positive theory of public bureaucracy', in D.C. Mueller(ed.), Perspectives on public choice, pp. 455-480, Cambridge University Press, Cambridge.

Mzenzi, S.I. \& Gaspar, A.F., 2015, 'External auditing and accountability in the Tanzanian Local Government authorities', Managerial Auditing Journal 30(6/7), 681-702. https://doi.org/10.1108/MAJ-04-2014-1028

Napier, C., 1998, 'Intersections of law and accountancy: Unlimited auditor liability in the United Kingdom', Accounting, Organizations and Society 23(1), 105-128. https://doi.org/10.1016/S0361-3682(97)00006-8

Norton, S.D, \& Smith, L.M., 2008, 'Contrast and foundation of the public oversight roles of the U.S. Government Accountability Office and the...', Public Administration Review 68(5), 921-931. https://doi.org/10.1111/j.1540-6210.2008.00932.x

Okpala, K.E., 2012, 'Fiscal accountability dilemma in Nigeria Public Sector: A warning model for economic retrogression', Research Journal of Finance and Accounting 3(6), 113-131.

Olken, B.A., 2007, 'Monitoring corruption: Evidence from a field experiment in Indonesia', Journal of Political Economy 115(2), 200-249. https://doi. org/10.1086/517935
Owusu, E.K., Chan, A.P.C., Hosseini, M.R. \& Nikmehr, B., 2020, 'Assessing procurement irregularities in supply-chain of Ghanaian construction projects: A soft-computing approach', Journal of Civil Engineering and Management 26(1), 66-82. https:// doi.org/10.3846/jcem

Rennie, M.D., Kopp, L.S. \& Lemon, W.M., 2014, 'Auditor-client disagreements and independence: An exploratory field study', in C. Jeffrey (ed.), Research on professional responsibility and ethics in accounting, pp. 131-161, Emerald Group Publishing Limited, Bingley.

Renas, S.M., \& Cebula, R.J., 2005, 'Enron, herding, and the deterrence effect of disclosure of improprieties', The American Journal of Economics and Sociology 64(3), 743-756. https://doi.org/10.1111/j.1536-7150.2005.00390.x

Republic of South Africa, 2005, Intergovernmental Relations Framework Act 13 of 2005, Government Printer, Pretoria.

Republic of South Africa, 2018, Public Audit Amendment Act 5 of 2018, Government Printer, Pretoria.

Republic of South Africa, Auditor-General of South Africa, 2007, Municipal Finance Management Act (MFMA) General report, Government Printer, Pretoria.

Republic of South Africa, Auditor-General of South Africa, 2017, Municipal Finance Management Act (MFMA) General report, Government Printer, Pretoria.

Republic of South Africa, Auditor-General of South Africa, 2018, Public Finance Management Act (PFMA) General report, Government Printer, Pretoria.

Republic of South Africa, Auditor-General of South Africa, 2019, Annual report annual report, Government Printer, Pretoria.

Republic of South Africa, Auditor-General of South Africa, 2020a, Municipal Finance Management Act (MFMA) General report, Government Printer, Pretoria.

Republic of South Africa, Auditor-General of South Africa, 2020b, Public Finance Management Act (PFMA) General report, Government Printer, Pretoria.

Republic of South Africa, Department of Provincial Treasury of the Northern Cape Provincial Administration, 2021, Persal Management report, Government Printer, Pretoria.

Rosa, C.P. \& Morote, R.P., 2016, 'The audit report as an instrument for accountability in local governments: A proposal for Spanish municipalities', International Review of Administrative Sciences 82(3), 536-558. https://doi.org/10.1177/002085231 4566000

Salant, P. \& Dillman, D.A., 1994, How to conduct your survey, Wiley, New York, NY.

Salleh, Z. \& Stewart, J., 2012a, 'The role of the audit committee in resolving auditorclient disagreements: A Malaysian study', Accounting, Auditing \& Accountability Journal 25(8), 1340-1372. https://doi.org/10.1108/09513571211275506

Salleh, Z. \& Stewart, J.D., 2012b, 'The impact of expertise on the mediating role of the audit committee', Managerial Auditing Journal 27(4), 378-402. https://doi. org/10.1108/02686901211217987

Saunders, M., Lewis, P. \& Thornhill, A., 2009, Research methods for business students, Pearson Education, Essex.

Schneider, A. \& Wilner, N., 1990, 'A test of audit deterrent to financial reporting irregularities using the randomised response technique', The Accounting Review 65(3), 668-681. https://www.jstor.org/stable/247956

Schneider, A \& Wilner, N., 1992, 'Evidence of auditing as a deterrent to financial reporting irregularities', Mid-American Journal of Business 7(1), 24-28. https:// doi.org/10.1108/19355181199200004

Tabish, S.Z.S. \& Jha, K.N., 2011, 'Analyses and evaluation of irregularities in public procurement in India', Construction Management and Economics 29(3), 261-274. https://doi.org/10.1080/01446193.2010.549138

Thanh, N.C. \& Thanh, T.T., 2015, 'The interconnection between interpretivist paradigm and qualitative methods in education', American Journal of Educational Science $1(2), 24-27$

Transparency International, 2011, Corruption perceptions Index report 2018 \& 1996, viewed 24 July 2021, from http://cpi.transparency.org/cpi2020/results/.

Uecker, W.C., Brief, A.P. \& Kinney, W.R., 1981, 'Perception of the internal and external auditor as a deterrent to corporate irregularities', The Accounting Review 56(3), 465-478. https://www.jstor.org/stable/246909

Warmoll, C., 2015, 'Deloitte resigns Ranger's audit brief after threats to staff', viewed 25 June 2021, from https://www.accountancyage.com/ 2015/07/07/deloitteresigns-rangers-audit-brief-after-threats-to-staff/.

Zaum, D., 2016, Public Financial Management and Corruption. GSDRC Professional Development Reading Pack no.42, University of Birmingham, Birmingham. 